\title{
Upaya Penurunan Energi di Bidang Konstruksi dalam Rangka Mengurangi Dampak Pemanasan Global
}

\author{
SUBRATA ADITAMA K. A. UDA dan MOCHAMAD AGUNG WIBOWO \\ Program Studi Doktor Teknik Sipil Fakultas Teknik Universitas Diponegoro \\ Email: subrataaditama@jts.upr.ac.id
}

\begin{abstract}
ABSTRAK
Bangunan hijau (green building) merupakan salah satu upaya menekan pengaruh negatif kegiatan konstruksi terhadap keberlanjutan lingkungan. Penelitian ini bertujuan mencari upaya dalam menurunkan Embodied Energy (energy terkandung) dan Operational Energy (energi yang digunakan selama masa umur bangunan) pada bangunan konstruksi dalam rangka mengurangi dampak terhadap pemanasan global berdasarkan studi literatur. Metode penelitian dengan pendekatan metode kualitatif dengan mengidentifikasi dan mereview beberapa literatur yang berhubungan dengan upaya penurunan energi pada proyek konstruksi. Hasil penelitian berupa rekomendasi dalam upaya meminimalkan energi yaitu menerapkan peraturan secara tegas tentang green building pada sektor konstruksi, desain/perancangan yang dapat mengurangi energi dengan memanfaatkan cahaya serta sirkulasi udara yang maksimum untuk mengurangi penggunaan $A C$, memilih material yang rendah energi dan karbon, efisiensi pemanfaatan sumber daya alam dan menerapkan construction waste management plan, dan mengoptimalkan supply chain baik dalam distribusi material maupun peralatan konstruksi akan berdampak pada pengurangan jumlah energi dari bahan bakar dan karbon akibat transportasi yang digunakan.
\end{abstract}

Kata kunci: bangunan hijau (green building), embodied energy, operational energy. 


\section{PENDAhUlUAN}

Pemanasan global (global warming) serta perubahan iklim yang ekstrim saat ini merupakan bahaya yang nyata bagi seluruh dunia. Hal ini tidak hanya membawa pengaruh negatif bagi mahluk hidup namun juga membawa dampak kerusakan bagi keberlangsungan mahluk hidup itu sendiri. Dampak pemanasan global (global warming) di Indonesia yaitu adanya musim kemarau yang panjang terjadi di beberapa wilayah seperti Kalimantan dan Sumatera. Akibat kekeringan akan memicu timbulnya kebakaran hutan yang menghasilkan gas $\mathrm{CO} 2$ sebagai faktor utama pembentuk efek rumah kaca di atmosfer, selain itu kebakaran hutan ini sangat menggangu aktifitas serta perekonomian di negara kita serta di sebagian wilayah negara-negara ASEAN. Asap akibat kebakaran hutan sangat membahayakan bagi manusia dan dapat menimbulkan korban jiwa. Tercatat, di Asia Tenggara lebih dari 2.000 juta ton karbon dioksida diemisikan per tahun akibat kerusakan lahan gambut, 90\% di antaranya dari lahan gambut Indonesia (Santoso, 2015).

Sebagai catatan penting, kenaikan suhu global sampai $1^{\circ} \mathrm{C}$ akan menyebabkan $30 \%$ spesies mengalami resiko kepunahan, kenaikan suhu permukaan air laut sampai $27^{\circ} \mathrm{C}$, beresiko menimbulkan badai tropis (Sangkertadi, 2012). Pemanasan global telah terjadi dan diperkirakan akan terus melaju meningkat. Harapan untuk menahan atau mengendalikan lebih banyak tergantung pada perilaku manusia penghuni bumi ini. Upaya gerakan pembangunan berwawasan "hijau" dan penghijauan "nyata" sambil menghambat laju deforestasi serta gerakan lain untuk mengurangi emisi gas rumah kaca menjadi andalan dalam menghadapi bencana akibat pemanasan global tersebut (Sangkertadi, 2012).

Green building merupakan suatu konsep pembangunan yang mengarah pada struktur dan pemakaian proses yang memperhatikan lingkungan dan hemat sumber daya sepanjang siklus hidup bangunan tersebut, mulai dari pemilihan tempat sampai desain konstruksi, operasi, perawatan, renovasi, dan peruntuhan. Konsep ini memperluas dan melengkapi desain bangunan dalam hal ekonomi, utilitas, durabilitas, dan kenyamanan (USEPA, 2009).

Bangunan gedung menggunakan $40 \%$ dari energi global, dan menghasilkan emisi pada tahap konstruksi dan operasi (Dixit, 2012). Untuk itu perubahan iklim perlu diantisipasi melalui tindakan adaptasi dan mitigasi agar bisa meminimalisir bencana alam yang dipicu perubahan iklim. Perkotaan merupakan kawasan yang rentan terhadap perubahan iklim. Populasi penduduk perkotaan yang relatif lebih tinggi dibandingkan penduduk perdesaan berpotensi untuk berkontribusi lebih besar dalam menghasilkan gas rumah kaca. Daya dukung lingkungan perkotaan akan relatif lebih rendah. Lokasi kota-kota di Indonesia juga sebagian besar merupakan daerah pesisir pantai, sehingga lebih rentan terhadap bencana (APEKSI, 2016).

\section{KAJIAN LITERATUR}

Energi dalam pekerjaan konstruksi terbagi dua yaitu embodied energy (energy terkandung) dan operational energy (energi yang digunakan selama masa umur bangunan) (Ramesh, 2010). Pada Gambar 1 menunjukan siklus hidup energi pada bangunan dimana terdapat dua energi yang berperan yaitu embodied energy (energi terkandung) dan operational energy. Kedua energi ini berperan dalam empat tahapan siklus hidup bangunan. Embodied energy mulai terjadi mulia pada tahap produksi (manufacturing) khususnya material, tahap konstruksi dan tahap pembongkaran bangunan. Operational energy terjadi pada tahap bangunan digunakan serta saat kegiatan renovasi/perbaikan bangunan. 


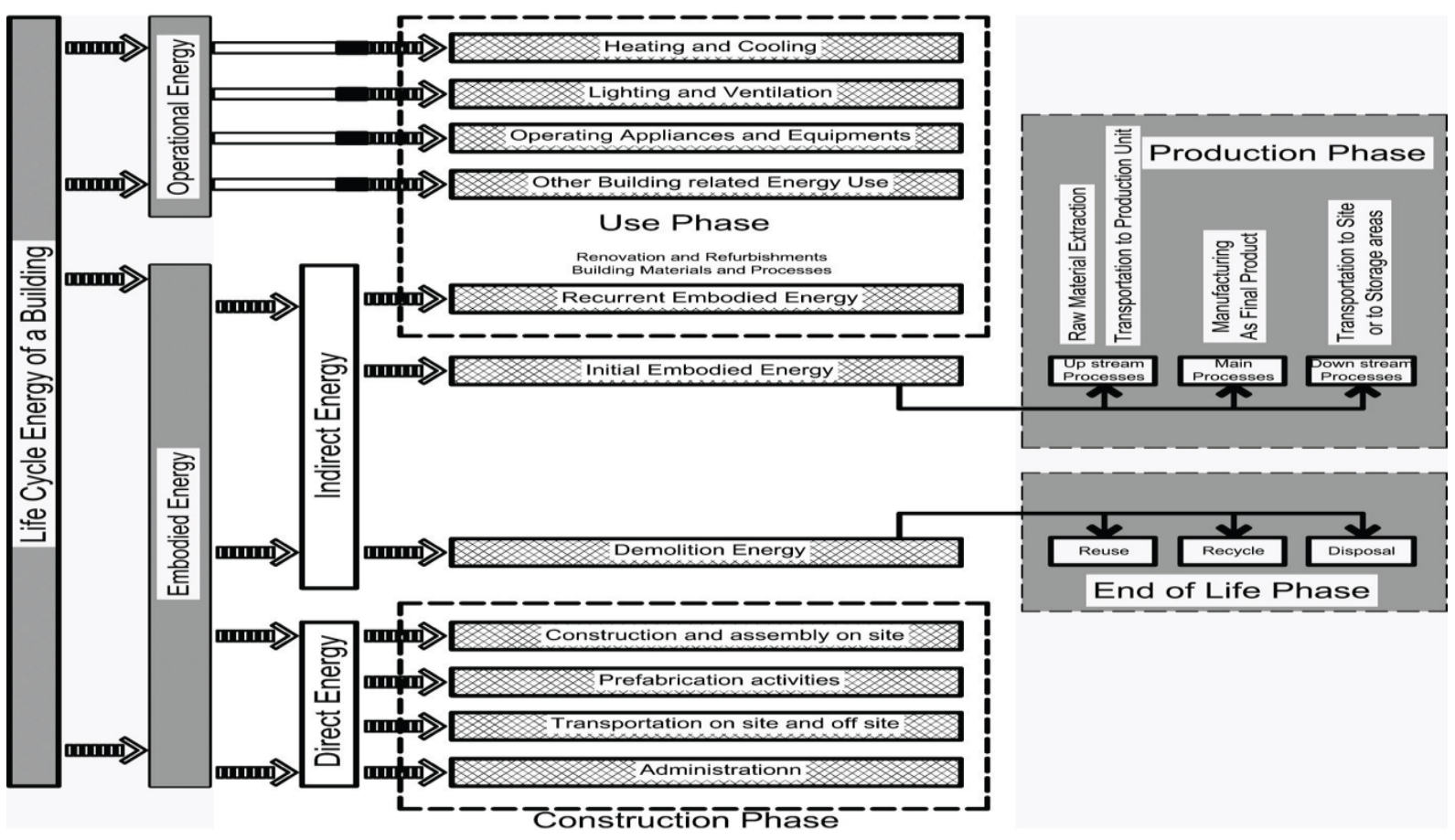

Gambar 1. Live Cycle Energy pada Bangunan (Sumber: Pullen, 1996)

\section{Definisi embodied energy (energy terkandung)}

Embodied energy (energi terkandung) didefinisikan sebagai energi total yang dibutuhkan dalam pembuatan bangunan, termasuk energi langsung yang digunakan dalam proses konstruksi dan energi tidak langsung yang dibutuhkan untuk memproduksi bahan dan komponen bangunan. Energi tidak langsung ini akan mencakup semua energi yang dibutuhkan dari bahan mentah ekstraksi bahan, melalui pengolahan dan pembuatan, dan juga mencakup semua energi digunakan dalam transportasi selama proses konstruksi dan bagian energi yang relevan yang terkandung dalam infrastruktur pabrik dan mesin manufaktur, konstruksi dan transportasi (Crowther, 1999).

Menurut Cleveland dan Morris (2009), embodied energy (energi terkandung) merupakan jumlah kebutuhan energi yang terkait, secara langsung atau tidak langsung, dengan pengiriman barang atau jasa. Sedangkan Edwards dalam Technical Guide (2010) menjelaskan bahwa embodied energy (energi terkandung) adalah energi yang dikonsumsi oleh semua proses yang terkait dengan produksi bangunan, dari pertambangan dan pengolahan sumber daya alam sampai manufaktur, pengangkutan dan pengiriman produk, dimana peran transportasi merupakan elemen utama dari energi material konstruksi yang terkandung.

Pada beberapa penelitian terdapat cara pandang yang berbeda dalam mendefinisikan embodied energy (energi terkandung) tergantung pada batasan studi yang dipilih. Tiga pilihan yang paling umum adalah: cradle-to-gate, cradle-to-site, dan cradle-to-grave (Densley, Tingley \& Davinson, 2011). Menurut Dixit, embodied energy (energi terkandung) atau EE: energi yang terdapat pada bangunan dan bahan bangunan selama proses produksi, pelaksanaan konstruksi, dan pembongkaran bangunan serta pembuangan sisa material. Secara keseluruhan, Energi yang terkandung dalam bangunan memiliki dua komponen utama, energi langsung dan energi tidak langsung: 
a. Energi langsung: energi dikonsumsi di tempat dan di luar kantor operasi, seperti konstruksi, prefabrikasi, perakitan, transportasi dan administrasi (Gambar 1).

b. Energi tidak langsung: energi yang dikonsumsi dalam pembuatan bahan bangunan, renovasi, perbaikan dan pembongkaran proses bangunan. Ini termasuk awal energi yang terkandung, energi dan pembongkaran yang terkandung berulang energi. Energi terkandung awal dikonsumsi selama produksi bahan dan komponen dan termasuk pengadaan bahan baku, pembuatan bahan bangunan dan pengiriman produk jadi (transportasi) ke lokasi konstruksi. Energi terkandung berulang digunakan di berbagai proses pemeliharaan dan pemugaran selama masa manfaat sebuah bangunan Pembongkaran energi dikeluarkan pada proses dekonstruksi dan pelepasan bangunan bahan bangunan (Gambar 1) (Dixit, 2010).

Dalam hubungan dengan tahapan siklus hidup bangunan (life cycle building (LCB)), embodied energy merupakan energi yang selalu menyertai disetiap kegiatan konstruksi. Berikut ini batasan sistem dalam kaitannya terhadap tahapan siklus hidup bangunan (Gambar 2) (BS. EN 15978, 2012; Balouktsi, 2016; Dixit, 2010).

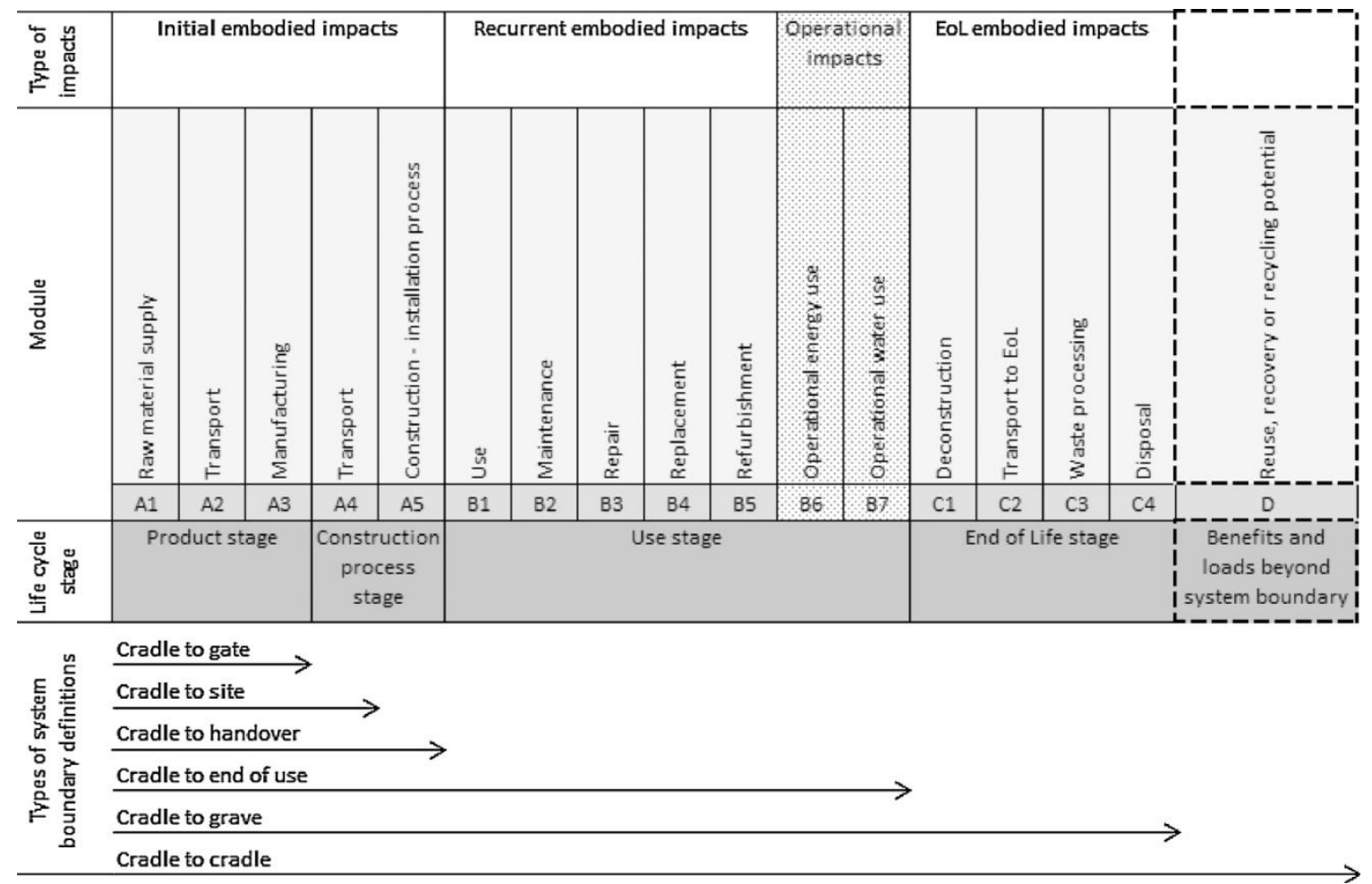

Gambar 2. Definisi batasan sistem dalam kaitannya dengan tahapan siklus hidup sebuah bangunan (Sumber: BS. EN 15978, 2012; Balouktsi, 2016; Dixit, 2012)

\section{Cradle-to-Gate}

Model cradle-to-gate hanya menggambarkan energi yang dibutuhkan untuk menghasilkan produk jadi tanpa pertimbangan lebih lanjut atau dengan kata lain jumlah energi pada tahap produksi (pasokan bahan baku, transportasi, manufaktur produk, dan semua proses hulu sampai pada proses siap untuk distribusikan).

\section{Cradle-to-Site}

Sebuah studi cradle-to-site mendefinisikan energi yang terkandung komponen bangunan individu sebagai energi yang dibutuhkan untuk mengekstrak bahan baku, proses mereka, merakit mereka menjadi produk yang dapat digunakan dan mengangkut mereka ke lokasi. 
Definisi ini berguna saat melihat skala komparatif komponen bangunan dan berhubungan lebih dengan "baik" dalam definisi Cleveland \& Morris karena mengabaikan biaya perawatan atau biaya akhir kehidupan.

\section{Cradle-to-Handover}

Tahapan Cradle-to-Handover merupakan lanjutan aktivitas setelah cradle-to-site, dimana pada fase ini jumlah energi yang terkandung diukur sejak tahapan proses konstruksi bangunan dan perakitan fasilitas bangunan sampai bangunan selesai.

\section{Cradle-to-End of Use}

Tahapan ini merupakan lanjutan aktivitas setelah cradle-to-handover ditambah dengan kegiatan pada proses pemeliharaan, perbaikan, penggantian, dan pemugaran, yang merupakan energi terkandung dan emisi yang berulang. Batasan ini menandai akhir penggunaan pertama bangunan.

\section{Cradle-to-Grave}

Tahapan cradle-to-grave mendefinisikan energi yang terkandung sebagai "dikonsumsi" oleh sebuah bangunan sepanjang hidupnya, tidak termasuk energi operasional yang dibutuhkan untuk menghasilkan produk akhir. Dimana tidak memperhitungkan pemanasan, pendinginan, pencahayaan dan kekuatan setiap peralatan yang memungkinkan bangunan untuk menjalani fungsi. Definisi ini jauh lebih jelas bila melihat bangunan atau proyek secara holistik, meski diakui jauh lebih kompleks untuk diperkirakan. Konsumsi energi bisa diuraikan lagi yaitu (Yohanis \& Norton, 2002):

1. Energi yang terkandung awal adalah energi yang dibutuhkan untuk awalnya menghasilkan bangunan. Ini termasuk energi yang digunakan untuk abstraksi, sering disebut sebagai energi primer, pengolahan dan pembuatan bahan bangunan serta transportasi dan perakitan di tempat.

2. Energi yang terkandung berulang adalah energi yang dibutuhkan untuk memperbaiki dan mempertahankan bangunan selama masa pakainya.

3. Energi pembongkaran adalah energi yang diperlukan untuk menghancurkan dan membuang bangunan di akhir hidupnya.

\section{Cradle-to-Cradle}

Tahapan cradle-to-cradle merupakan proses daur ulang / penggunaan kembali bahan material dimana pada fase ini jumlah energi diperhitungkan untuk semua atau sebagian dari produk yang didaur ulang atau digunakan kembali pada akhir masa pakainya.

\section{Definisi operational energy (energi operasional)}

Operational energy adalah energi yang ada digunakan untuk memenuhi kebutuhan energi di dalam lingkungan gedung atau bangunan. Dengan kata lain, semua energi yang ada digunakan ke sistem untuk mengoperasikan lampu, lift dan eskalator, sistem ventilasi, pemanasan dan sistem pendingin, sistem pemanas air dan pemompaan. Ini termasuk energi dari listrik, gas, dan pembakaran bahan bakar seperti minyak atau batu bara (Crowther, 1999).

Konsumsi energi operasional terbanyak umumnya ada pada gedung perkantoran. Hal ini perlu menjadi perhatian pada tahap desain dimana dalam merencanakannya harus memperhitungkan energi selama pengoperasian gedung. Energi operasional sering kali berkaitan dengan pemeliharaan lingkungan internal yang stabil, target penggunaan energi ini akan sangat bervariasi tergantung pada kebutuhan dan fungsi bangunan serta lingkungan 
disekitarnya. Oleh karena itu, di beberapa negara sudah mentapkan nilai target secara terukur untuk penggunaan energi operasional pada bangunan. Nilai target pada bangunan gedung umumnya berkisar $290 \mathrm{MJ} /$ a.m² sampai $1.210 \mathrm{MJ} / \mathrm{a} . \mathrm{m}^{2}$ (BOMA, 1994; Jaques 1996; Suzuki, 1998).

Penelitian dan penyelidikan sebelumnya menegaskan bahwa energi operasional sejauh ini merupakan penyumbang terbesar terhadap total konsumsi energi dalam siklus kehidupan bangunan. Ini dapat mencakup sekitar $80 \%$ dari total konsumsi energi dalam siklus hidup bangunan (Ramesh, Prakash, \& Shukla, 2010). Saat ini para peneliti lebih terfokus pada pengurangan energi operasional, sementara energi yang terkandung dan energi pembongkaran kurang mendapat perhatian. Beberapa penelitian menyebutkan bahwa energi pada fase pembongkaran hanya mewakili $1 \%$ dari total energi siklus hidup bangunan (Aye, Ngo, Crawford, Gammampila, \& Mendis, 2012). Penelitian terbaru menunjukkan bahwa energi yang terkandung dapat mencapai sekitar $40 \%$ dari total energi yang digunakan selama masa hidup bangunan (Huberman \& Pearlmutter, 2008).

\section{METODE}

Artikel ini menggunakan pendekatan metode kualitatif dengan cara mengidentifikasi dan mereview beberapa literatur yang berhubungan dengan upaya penurunan energi pada proyek konstruksi. Studi literatur ini bertujuan untuk menganalisa dan mengungkapkan temuan dan pandangan para peneliti sebelumnya tentang energi dan mencoba mengklasifikasikan isi penelitian kedalam lingkup life cycle project (LCP). Berdasarkan pandangan tersebut perumusan permasalahan penelitian yang berkaitan dengan embodied energy dan operational energy, dapat dipetakan dengan lebih jelas.

Penelitian ini menggunakan sumber data sekunder berupa studi literatur yang diambil dari jurnal jurnal internasional dengan teknik pengumpulan data purposive sampling dimana dilakukan reduksi data dengan memfokuskan pencarian pada preseden yang memiliki topik penelitian dengan embodied energy dan operational energy pada sektor konstruksi. Melalui topik penelitian tersebut dapat diketahui parameter penelitian yang biasa digunakan peneliti untuk mengusulkan upaya minimalisasi energi. Jurnal penelitian yang dijadikan sampel sebanyak 10 buah dengan menekankan analisis data pada parameter dan metodologi yang digunakan dalam area studi penelitian.

Data jurnal yang digunakan mempunyai rentang empat tahun penelitian terkini yaitu antara tahun 2014 sampai tahun 2018. Metode analisis data dilakukan dengan cara pemetaan masing-masing topik penelitian dari jurnal tersebut yang dibuat dalam bentuk tabel. Selanjutnya dilakukan analisis deskriptif yang memuat interpretasi dari tabel analisis tersebut. Pada artikel ini masih dalam proses penelitian sehingga dimungkinkan untuk dilakukan pengembangan literatur. Berikut ini terdapat 10 literatur yang memiliki kedekatan dengan langkah atau upaya minimalisasi energi pada sektor konstruksi. Adapun hasil pemetaan jurnal penelitian tersebut seperti pada Tabel $\mathbf{1}$ di bawah ini. 
Upaya Penurunan Energi di Bidang Konstruksi dalam Rangka Mengurangi Dampak Pemanasan Global

Tabel 1. Penelitian tentang Embodied energy(EE) dan Operational energy(OE)

\begin{tabular}{|c|c|c|c|c|c|c|c|}
\hline \multirow[t]{2}{*}{ References } & \multirow[t]{2}{*}{ Years } & \multirow[t]{2}{*}{ Location } & \multirow{2}{*}{$\begin{array}{c}\text { Type of } \\
\text { Research } \\
\text { /Analysis }\end{array}$} & \multirow{2}{*}{$\begin{array}{l}\text { Type of } \\
\text { Construction }\end{array}$} & \multicolumn{2}{|c|}{$\begin{array}{l}\text { Energy } \\
\text { Studied } \\
\end{array}$} & \multirow[t]{2}{*}{ Case Study } \\
\hline & & & & & $\overline{E E}$ & $\overline{O E}$ & \\
\hline Shoubi et al. & 2014 & Malaysia & $\begin{array}{c}\text { Building Information } \\
\text { Modelling (BIM) }\end{array}$ & Residential & - & $x$ & $\begin{array}{c}2 \text { story - } \\
\text { Bungalow House }\end{array}$ \\
\hline Malmqvist et al. & 2014 & UE & $\begin{array}{c}\text { Comparing Study / } \\
\text { Literrary Study }\end{array}$ & $\begin{array}{l}\text { Building \& } \\
\text { Residential }\end{array}$ & $x$ & - & $\begin{array}{c}\text { Building } \\
\text { Construction } \\
\end{array}$ \\
\hline $\begin{array}{l}\text { Efstratios } \\
\text { and Alice }\end{array}$ & 2014 & UK & Quasy-Experimental & Building & $x$ & - & $\begin{array}{c}\text { Building } \\
\text { Construction }\end{array}$ \\
\hline Krantz et al & 2015 & Sweden & $\begin{array}{l}\text { LCA-Experimental, } \\
\text { Modelling }\end{array}$ & Infrastructure & $x$ & - & $\begin{array}{c}\text { Bridge } \\
\text { Construction }\end{array}$ \\
\hline Carbonaro et al. & 2015 & Italy & $\begin{array}{c}\text { Experimental } \\
\text { Material } \\
\end{array}$ & $\begin{array}{l}\text { Building \& } \\
\text { Residential }\end{array}$ & $x$ & $x$ & Building Material \\
\hline Abanda and Byers & 2016 & UK & $\begin{array}{c}\text { Building Information } \\
\text { Modelling (BIM) }\end{array}$ & Residential & - & $x$ & 3 story - House \\
\hline Lolli et al. & 2017 & Norwegian & $\begin{array}{l}\text { Energy Modelling, } \\
\text { LCA, } \\
\text { Parametric Analysis }\end{array}$ & Building & $x$ & $x$ & Building Material \\
\hline Giordano et al. & 2017 & USA \& UE & $\begin{array}{c}\text { Experimental, } \\
\text { Modelling }\end{array}$ & Building & $x$ & $x$ & $\begin{array}{l}\text { Construction } \\
\text { Element }\end{array}$ \\
\hline Rasmussen et al. & 2018 & UE & $\begin{array}{l}\text { Comparing Study / } \\
\text { Literrary Study }\end{array}$ & Building & $x$ & - & $\begin{array}{c}\text { Building } \\
\text { Construction }\end{array}$ \\
\hline $\begin{array}{l}\text { Shadram } \\
\text { and Mukkavaara }\end{array}$ & 2018 & Sweden & $\begin{array}{c}\text { BIM, } \\
\text { Framework Model }\end{array}$ & $\begin{array}{l}\text { Building \& } \\
\text { Residential }\end{array}$ & $x$ & $x$ & $\begin{array}{l}\text { Construction } \\
\text { Element }\end{array}$ \\
\hline
\end{tabular}

(Sumber: Subrata Aditama, K. A. U., 2017)

\section{HASIL DAN PEMBAHASAN}

Pada Tabel 1 ditampilkan beberapa literatur yang meneliti tentang EE dan OE dengan tipe penelitian/analisis yang berbeda-beda untuk mencari upaya penurunan energi pada bidang konstruksi terhadap pengaruh lingkungan. Metode analisis BIM digunakan untuk memodelkan bangunan dalam mencari elemen bangunan yang memiliki tingkat energi terbesar, dimana dari elemen tersebut dilakukan rekayasa material atau design sehingga nilai energi menjadi lebih rendah. Pada studi literatur ini metode BIM banyak digunakan untuk bangunan perumahan (Shoubi et al., 2014; Abanda and Byers, 2016; Shadram and Mukkavaara, 2018). Terdapat 3 buah literatur yang menggunakan analisis eksperimental baik dengan menggunakan kuesioner, material, dan modeling pada struktur (Efstratios and Alice, 2014; Carbonaro et al., 2015; Giordano et al, 2017). Upaya dalam rangka menemukan strategi yang tepat untuk mengurangi energi dapat dilakukan dengan cara survei data, observasi lapangan serta penggalian informasi dari para ahli konstruksi (Efstratios and Alice, 2014), disamping itu analisis terhadap material dapat dilakukan dengan mengidentifikasi dan menganalisis material penghasil energi terbesar dalam komponen bangunan dalam hal ini semen sebagai bahan utama dalam kegiatan plasteran dinding bangunan (Carbonaro et al., 2015). Rekayasa tampak bangunan terutama pada penutup bangunan dengan menggunakan material yang berbeda-beda dapat mempengaruhi tingkat energi pada bangunan tersebut, untuk itu perlu mempertimbangkan jenis material yang digunakan dengan cara memodellkan (Giordano et al., 2017).

Analisis LCA banyak digunakan untuk menilai tingkat energi dan karbon pada bangunan. Analisis ini meninjau alur energi yang terjadi selama siklus bangunan sehingga dapat diketahui pada tahapan mana yang memiliki penguruh tertinggi terhadap energi. Analisis LCA dapat dilakukan dengan metode parametik, eksperimental atau modeling (Krantz et al., 
2015; Lolli et al., 2017). Analisis komperasi studi atau studi literatur digunakan untuk memetakan beberapa masukkan dan usulan alternatif analisis dari beberapa peneliti sehingga diketahui perkembangan penelitian yang dalam hal ini penelitian yang bertujuan untuk upaya menurunkan pengaruh energi yang berdampak pada kondisi lingkungan (Malmqvist et al., 2014; Rasmussen et al., 2018).

Pada literatur di atas untuk tipe konstruksi bangunan terdapat 3 jenis, yaitu perumahan, gedung, dan infrastruktur; dengan tinjauan studi kasus pada elemen bangunan rumah, konstruksi dan struktur bangunan gedung, material bangunan dan elemen struktur jembatan. Pada literatur di atas terbanyak meninjau upaya penurunan Embodied Energy dengan 4 literatur (Malmqvist et al., 2014; Efstratios and Alice, 2014; Krantz et al., 2015; Rasmussen et al., 2018), literatur yang meninjau Operational Energy sebanyak 2 buah (Shoubi et al., 2014; Abanda and Byers, 2016) sedangkan yang menunjau dari kedua energi baik EE dan OE sebanyak 4 literatur (Carbonaro et al., 2015; Shadram and Mukkavaara, 2017; Lolli et al., 2017; Giordano et al., 2017).

Ada beberapa rekomendasi yang diusulkan oleh para peneliti tersebut dalam upaya menurunkan pengaruh embodied energy dan operational energy. Berikut hasil rekomendasi tersebut:

1. Integrasi konsep BIM ke dalam tahap desain dapat digunakan untuk mencegah dampak yang merugikan lingkungan serta akan meminimalkan biaya energi. Selain itu desain bangunan yang lebih efisien dan berkelanjutan, peningkatan kinerja bangunan, dan meminimalkan risiko lingkungan dapat membantu dalam mengurangi konsumsi energi. (Shoubi et al., 2014; Abanda and Byers, 2016; Shadram and Mukkavaara, 2018).

2. Material bangunan merupakan faktor terbesar yang mempengaruhi embodied energy dan operational energy. Dengan memaksimalkan penggunaan material ramah lingkungan akan mampu menurunkan efek energi pada bangunan. Material terbesar yang mempengaruhi bangunan yaitu semen, baja, besi dan keramik. Selain itu dengan menggunakan metode LCA akan mampu menganalisis potensi energi baik embodied energy maupun operational energy sehingga akan mempermudah dalam membuat strategi efisiensi energi (Krantz et al., 2015; Carbonaro et al., 2015; Giordano et al., 2017; Lolli et al., 2017).

3. Pada studi literatur ditemukan bahwa peran standar atau aturan suatu negara dalam menurunkan pengaruh energi terhadap dampak lingkungan sangat tinggi. Dengan memperketat ketentuan atau aturan tersebut maka semua pelaku konstruksi akan sejalan dalam menurunkan energi baik embodied energy maupun operational energy (Malmqvist et al., 2014; Rasmussen et al., 2018).

4. Penggunaan bahan daur ulang dari sisa bongkaran serta mengurangi limbah konstruksi dengan sistem manajemen limbah/ waste management merupakan salah satu strategi untuk menurunkan embodied energy (Efstratios and Alice, 2014; Malmqvist et al., 2014).

5. Pemanfaatan analisis parametrik yang mengoptimalkan penggunaan energi operasional, emisi $\mathrm{CO}_{2}$ eq yang diwujudkan, dan penggunaan energi yang terkandung, melalui pengujian alat dengan model bangunan konseptual akan berdampak pada cara bangunan dirancang lebih mempermudah mendesain bangunan rendah energi (Lolli et al., 2017).

6. Perancangan yang memperhatikan kemudahan dalam sistem pembongkaran bangunan akan lebih menghemat energi serta menurunkan karbon selain itu limbah juga akan mudah untuk dipilah dan didaur ulang (Efstratios and Alice, 2014)

7. Perancangan bangunan yang mengoptimalkan pemanfaatan cahaya pada ruang akan mampu mengurangi operational energy lebih besar (Giordano et al., 2017). 


\section{KESIMPULAN}

Bangunan gedung menggunakan $40 \%$ dari energi global, dan menghasilkan emisi pada tahap konstruksi dan operasi, dimana terdapat dua jenis energi yang berpengaruh yaitu embodied energy dan operational energy. Embodied energy (EE) terjadi disepanjang siklus hidup bangunan sedangkan operatonal energy terjadi pada saat bangunan digunakan. Besarnya energi yang terjadi tergantung pada model desain atau perancangan, pemilihan material bangunan, metode pelaksanaan konstruksi dan limbah konstruksi yang dihasilkan. Terdapat 7 (tujuh) rekomendasi yang dirangkum dari 10 (sepuluh) literatur yang berhubungan dengan upaya penurunan energi terhadap dampak lingkungan. Rekomendasi ini didasarkan pada hasil analisis literatur, LCA, experimental, modelling, BIM serta parametik analisis.

Dari literatur diatas peneliti mengambil suatu kesimpulan untuk meminimalkan energi, yaitu: pemerintah harus secara tegas menerapkan aturan tentang pembangunan ramah lingkungan (green building), desain/perancangan mengutamakan pengurangan energi dengan memanfaatkan cahaya serta sirkulasi udara yang maksimum untuk meminimalkan penggunaan $\mathrm{AC}$, memilih material yang rendah energi dan karbon, efisiensi pemanfaatan sumberdaya alam dan mengurangi sisanya pada tahap konstruksi atau pembongkaran bangunan dengan melakukan construction waste management plan dan mengoptimalkan supply chain baik dalam distribusi material maupun peralatan konstruksi akan berdampak pada pengurangan jumlah energi dari bahan bakar dan karbon akibat transportasi yang digunakan.

Rekomendasi ini diharapkan akan memberikan dampak yang signifikan dalam upaya mengurangi energi baik embodied energi maupun operasional energi. Untuk penelitian kedepan sebaiknya diarahkan pada penelitian eksperimental yang menghasilkan inovasi material terbarukan yang ramah lingkungan, energi dan karbon.

\section{DAFTAR RUJUKAN}

Abanda, F. H. and Byers, L. (2016). An Investigation of the Impact of Building Orientation on Energy Consumption in a Domestic Building Using Emerging BIM (Building Information Modelling). Journal of Energy, 97(C), 517-527.

APEKSI. (2016). __, Dipetik 7 Desember, 2017, dari Workshop Kota Berketahanan Strategi Pembangunan Infrastruktur Permukiman dalam Menghadapi Perubahan Iklim: http://apeksi.id/index.php/12-berita/nasional/1113

Aye, L., Ngo, T., Crawford, R. H., Gammampila, R., Mendis, P. Life cycle greenhouse gas emissions and energy analysis of prefabricated reusable building modules. Energy Build, 47(2012), 159-168.

Balouktsi, M., Lützkendorf, T. (2016). Energy Efficiency of Buildings: The Aspect of Embodied Energy. Energy Technology, 4(1), 31-43.

BSI. (2012). BS.EN 15978:2011 - Sustainability of construction works. Assessment of enviromental performance of buildings. Calculation method.

Building Owners and Managers Association of Australia (BOMA). (1994). BOMA energy guidelines, Previous edition: Advisory guidelines towards an energy policy for building owners and managers. Victoria, Australia: Building Owners and Managers Association of Australia (BOMA).

Carbonaro, C., Casconeb, Y., Fantuccib, S., Serrab, V., Perinob, M. Duttoc, M. (2015, Juni 14-17). Energy Assessment of A PCM-Embedded Plaster: Embedded Energy versus 
Operational Energy. In Perino, M. et al. (Ed.), $6^{\text {th }}$ International Building Physics Conference, IBPC 2015 (p. __-_). _ _ Curran Associaties, Inc.

Cleveland, C. J. \& Morris, C. G. (2009). Dictionary of Energy: Expand Edition. USA: Elsevier Science.

Crowther, P. (1999, September 22-24). Design for Disassembly to Recover Embodied Energy. In S. S. Szokolay (Ed.), $16^{\text {th }}$ International Conference on Passive and Low Energy Architecture (p. ____ ). Melbourne: QUT ePrints.

Densley T. D. \& Davidson, B. (2011). Design for deconstruction and material reuse. In (Ed.), Institution of Civil Engineers-Energy (pp. 164, 195-204).

Dixit at al, 2010, Identification of parameters for embodied energy measurement: $A$ literature review, Energy and Buildings 42 (2010) 1238-1247, journal homepage: www.elsevier.com/locate/enbuild, USA.

Dixit, M. K., Solis, J. L. F., Lavy, S., Clup, C. H. (2012). Need for An Embodied Energy Measurement Protocol for Buildings: A review paper. Journal of Renewable nd Sustainable Energy Reviews, 16 (6), 3730-3743.

Edwards, B. Rough Guide to Sustainability, $3^{\text {rd }}$ Ed. London: RIBA Publishing.

Efstrations, G., Alice, M. (2014, October 28-30 $\left.{ }^{\text {th }}\right)$. Practical limitations in Embodied Energy and Carbon Measurements, and How to Adress Them: a UK Case Study. Sustainable Building Conference WSB14 (pp. 1-8). Barcelona: The Open University.

Giordano, R., Giovanardi, M., Guglielmo, G., Micono, C. (2017, Oktober). Embodied Energy and Operational Energy Evaluation in Tall Buildings According to Different Typologies of Façade. _ (Ed.), $9^{\text {th }}$ International Conference on Sustainability in Energy and Buildings, SEB-17, 5-7 July 2017 (pp. 224-233). Chania, Crete: Energy Procedia.

Huberman, N., Pearlmutter, A. D. life-cycle energy analysis of building materials in the Negev desert. Energy Build, 40 (2008), 837-848.

Jaques, R. (1996, 28-29 November). Energy EFFICIENCY BUILDING STANDARDS PROJECT REVIEW OF EMBODIED ENERGY. In G. F. Treloar (Ed.), Embodied Energy Seminar: Current State of Play (p. __). Geelong: Deakin University.

Krantz, J. Larsson, J., Lu, W., and Olofsson, M. Assessing Embodied Energy and Greenhouse Gas Emissions in Infrastructure Projects. Journal of Buildings , 5(4), 1156-1170.

Lolli, N., Fufab, S. M., Inmanb, M. (2016, September 11-13). A Parametric Tool for the Assessment of Operational Energy Use, Embodied Energy and Embodied Material Emissions in Building. $8^{\text {th }}$ International Conference on Sustainability in Energy and Buildings, SEB-16 (p. __ ). Turin: Energy Procedia .

Malmqvist, T., Birgisdóttir, H., Wiberg, A. H., Moncaster, A., Brown, N., John, V., Passer, A., Potting, J., Soulti, E. (2014, October 28-30th). Design Strategies for Low Embodied Energy and Greenhouse Gases in Buildings: Analysis of the IEA Annex 57 Case Studies. In editor (Ed.), World Sustainable Building Conference WSB14 (p. ). Barcelona:

Pullen, S. (1996). Data Quality of Embodied energy methods. In _ (Ed.), Embodied energy seminar: current state of play (p. _- ). _ :

Ramesh, T., Prakash, R., Shukla, K. (2010). Life cycle energy analysis of buildings: an overview. Energy Build, 42 (10), 1592-1600.

Rasmussen, F. N., Malmqvist, T., Moncaster, A., Wiberg, A.H., Birgisdóttir, H. (2018). Analysing Methodological Choices in Calculations of Embodied Energy and GHG Emissions from Buildings. Jornal of Energy and Buildings, 158 (1 Jan 2018), 1487-1498.

Sangkertadi. (2012). __. Dipetik Agustus 2016, dari NMP MASA - researchgate.net: http://www.researchgate.net/publication/305767399

Santoso, N. (2015, November 04). Dipetik _ _, _, dari Koran Sindo: https://nasional.sindonews.com/read/1058676/18/kebakaran-hutan-gambut-globalwarming-1446577496/ 
Shadram, F., Mukkavaara, J. (2018). An Integrated BIM-Based Framework for the Optimization of the Trade-Off between Emodied and Operational Energy. Journal of Energy and Buildings, 158 (2018), 1189-1205.

Shoubi, M. V., Bagchi, A., Barough, A. S. (2014). Reducing the Operational Energy Demand in Buildings Using Building Information Modelling Tools and Sustainbility Approaches. Journal of Ain Shams Engineering , 6 (March 2015), 41-55.

Suzuki, M., Oka, T., Estimation of life cycle energy consumption and $\mathrm{CO}_{2}$ emission of office buildings in Japan. Energy and Buildings , $28(1)$, 33-41.

U. S. Enviromental Protection Agensy (USEPA). (2009). Dipetik 15 Oktober, 2017, dari _ : http://www.epa.gov/greenbuilding/pubs/about.htm

Yohanis, Y. G. Norton, B. (2002). Life-cycle operational and embodied energy for a generic single-storey office building in the UK. Energy , 27(2002), 77-92. 